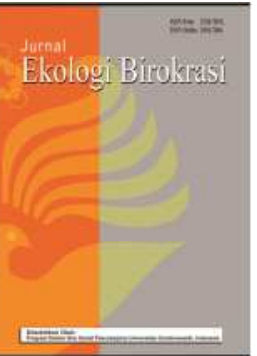

\title{
Struktur dan Tata Ruang Sosial Budaya Suku Bangsa Yokari Kabupaten Jayapura Provinsi Papua
}

\author{
Mais Maikel Yaroseray \\ Program Doktor Ilmu Sosial Pascasarjana Universitas Cenderawasih, Indonesia \\ Email: maisyariser@gmail.com
}

\section{INFO ARTIKEL}

\section{Kata Kunci:}

Struktur; Tata Ruang;

Sosial Budaya; Yokari

Cara Mengutip:

Yaroseray, M.M. (2018). Struktur dan Tata Ruang Sosial Budaya Suku Bangsa Yokari Kabupaten Jayapura Provinsi Papua. Jurnal Ekologi Birokrasi, 6 (3): $40-58$

DOI:

10.31957/jeb.v0i0.782

\section{ABSTRAK}

Suku di Papua rata-rata memiliki struktur sosial dan tata ruang kebudayaan beraneka ragam yang berperan penting dalam kehidupan sosial dan budaya mereka. Sistem yang mengatur hubungan atau relasi antar warga dalam berbagai aktivitas hidupnya sehari-hari berdasarkan kebudayaan mereka masing-masing, yaitu sistem politik atau sistem kepemimpinan politik tradisional. Jenis penelitian ini adalah deskriptif dengan pendekatan etno metodologi studi lapangan. Penelitian dilakukan di Distrik Yokari pada kebudayaan suku bangsa Yokari Kabupaten Jayapura Provinsi Papua.

Struktur sosial yang berbentuk kelompok kelompok klenklen dalam suku bangsa Yokari yang terbagi menjadi empat kelompok besar yaitu (1) Kaniyo, sebagai kelompok yang berkuasa atas tanah, (2) Yowari, adalah kelompok yang berhubungan dengan religi, (3) Yepei, adalah kelompok yang berhubungan dengan pemerintahan, serta pengamanan terhadap suku bangsa dari serangan musuh, dan (4) Yepei Yowari, adalah kelompok ini berperan baik sebagai kelompok pemerintahan dan juga religi. Masingmasing kelompok tersebut, menguasai runag darat, laut dan udara, dibawah pengendalian ondoafi berdasarkan norma-norma yang berlaku. Tata ruang suku bangsa Yokari adalah ruang darat yang dikuasai oleh kelompok Kaniyo, seperti tanah dan hutan, serta sumber mata pencaharian hidup yang terdapat di darat dan permukiman. Ruang laut dikuasai oleh kelompok Kaniyo dan Yowari, berkaitan dengan penangkapan ikan dan pengetahuan tentang terumbu karang. Ruang udara dikuasai oleh klen Soning Yufu.

\section{Hak Cipta@ 2018 JEB. Seluruh Hak Cipta.}




\section{ARTICLE INFO}

Keywords:

Structure;

Yokari

How to Cite:

Yaroseray, M.M. (2018).

Struktur dan Tata Ruang

Sosial Budaya Suku

Bangsa Yokari Kabupaten

Jayapura Provinsi Papua.

Jurnal Ekologi Birokrasi,

6 (3): $40-58$

DOI:

10.31957/jeb.v0i0.782

\section{ABSTRACT}

Tribes in Papua on average have diverse social structures and spatial structures that play an important role in their social and cultural life. System that regulates relations or relations between citizens in various daily activities of life based on their respective cultures, namely the political system or traditional political leadership system. This type of research is descriptive with an ethno approach to field study methodology. The study was conducted in Yokari District on the culture of the Yokari ethnic group in Jayapura Regency, Papua Province. The social structure in the form of clusters of groups within the Yokari ethnic group is divided into four major groups, namely (1) Kaniyo, as the ruling group over land, (2) Yowari, is a group related to religion, (3) Yepei, is groups related to government, as well as safeguarding ethnic groups from enemy attacks, and (4) Yepei Yowari, this group plays a role both as a government group and also as a religion. Each of these groups controls land, sea and air, under ondoafi control based on prevailing norms. The layout of the Yokari ethnic group is a land space controlled by the Kaniyo group, such as land and forests, as well as living sources of livelihood on land and settlements. Sea space is controlled by Kaniyo and Yowari groups, related to fishing and knowledge of coral reefs. The air space is controlled by the Soning Yufu clan.

Copyright $\odot 2018$ JEB. All rights reserved.

\section{Pendahuluan}

Struktur sosial dalam kebudayaan di dunia terdapat berbagai perbedaan-perbedaan sesuai dengan tatanan nilai sosial. Jika kita berbicara mengenai struktur berarti mengacu kepada susunan hubungan antara komponen-komponen, seperti struktur kulit bumi, kimia yang mempelajari molekul-molekul, atau seperti struktur kalimat. Struktur ini juga terdapat pada kehidupan sosial manusia, memiliki komponenkomponen yang saling berhubungan satu sama lain. Masyarakat adalah sebuah struktur sosial yang terdiri dari jaringan hubungan sosial yang kompleks antara anggota-anggotanya. Suatu hubungan sosial antara dua orang anggota tertentu pada waktu tertentu, di tempat tertentu, tidak dipandang sebagai satu hubungan yang berdiri sendiri, tetapi merupakan bagian dari satu jaringan hubungan sosial yang luas, yang melibatkan keseluruhan anggota masyarakat tersebut. Hubungan kedua orang di atas harus dilihat sebagai bagian dari satu struktur sosial. Inilah prinsip dan objek kajian ilmu sosial, menurut Radcliffe-Brown (1940).

Individu-individu yang menjadi komponen dari sebuah struktur sosial dilihat sebagai person yang menduduki posisi atau status, di dalam struktur sosial tertentu. Orang sebagai status sosial; orang berhubungan dengan orang lain dalam kapasitasnya sendiri yang berlainan satu sama lain. Perbedaan-perbedaan status sosial tersebut menentukan bentuk hubungan sosial, dan atas dasar itu ia juga akan 
mempengaruhi struktur sosial. Suatu struktur sosial adalah total dari jaringan hubungan antar individu-individu, atau person-person dan kelompok person. Dimensinya ada dua, yaitu; hubungan diadik, artinya antar pihak (yaitu person atau kelompok) kesatu dengan pihak kedua. Juga diferensial, antara satu pihak dengan beberapa pihak yang berbeda-beda atau sebaliknya.

Bentuk dari struktur sosial adalah tetap, dan apabila berubah, proses tersebut biasanya berjalan lambat, sedangkan "realitas struktur sosial" atau wujud dari struktur sosial, yaitu person-person atau kelompok-kelompok yang ada di dalamnya, selalu berubah dan berganti. Tentu saja ada beberapa peristiwa yang membuat bentuk struktur sosial ini berubah, seperti peristiwa perang atau revolusi misalnya. Radcliffe-Brown (1940) dalam Syarif Moeis, yang menyatakan bahwa struktur sosial itu adalah suatu rangkaian kompleks dari relasi-relasi sosial yang berwujud dalam suatu masyarakat, struktur sosial itu mencakup seluruh hubungan antara individuindividu pada saat tertentu, oleh karenanya struktur sosial itu merupakan aspek nonprosesual dari sistem sosial, isinya adalah keadaan statis dari sistem sosial yang bersangkutan. Lebih jelas mengenai hal tersebut dengan istilah On Social Structure dalam pidatonya Radcliffe-Brown menerangkan bahwa: Masyarakat yang hidup di tengah-tengah alam semesta sebenarnya terdiri dari serangkaian gejala-gejala yang dapat kita sebut gejala sosial. Demikian juga banyak hal lain dalam alam semesta ini, seperti planet-planet yang beredar, organisma-organisma yang hidup, molekulmolekul yang bergerak; sebenarnya terdiri dari berbagai rangkaian gejala alam. Masyarakat yang hidup sebenarnya juga merupakan suatu klas dari gejala-gejala alam yang lain, dan dapat juga dipelajari dengan metodologi yang sama seperti metodologi yang dipergunakan untuk mempelajari gejala-gejala alam semesta yang lain. Suatu masyarakat yang hidup merupakan suatu sistem sosial, dan suatu sistem sosial mempunyai struktur juga seperti halnya bumi, organisma, makhluk, atau molekul. Suatu ilmu mengenai masyarakat seperti ilmu sosial, yang mempelajari struktur dan sistem-sistem sosial adalah sama halnya dengan ilmu geologi yang mempelajari struktur kulit bumi, atau ilmu biologi yang mempelajari struktur dari organisma-organisma, ilmu kimia yang mempelajari struktur dari molekul-molekul. Suatu struktur sosial merupakan total dari jaringan hubungan antara individuindividu, dan kelompok individu. "Bentuk dari struktur sosial" adalah tetap, dan apabila berubah, proses tersebut biasanya berjalan lambat, sedangkan "realitas struktur sosial" atau wujud dari struktur sosial, yaitu person-person atau kelompokkelompok yang ada di dalamnya, selalu berubah dan berganti.

Struktur sosial berada dalam satu ruang tatanan adat yang membentuk karakter hidup mereka, ruang adalah wadah yang meliputi ruang darat, ruang laut, dan ruang udara, termasuk ruang di dalam bumi sebagai satu kesatuan wilayah, tempat manusia dan makhluk lain hidup, melakukan kegiatan, dan memelihara kelangsungan hidupnya. Struktur ruang adalah susunan pusat-pusat permukiman dan sistem jaringan prasarana dan sarana yang berfungsi sebagai pendukung kegiatan sosial ekonomi masyarakat yang secara hierarkis memiliki hubungan fungsional.

Budaya mengatur sistem tata ruang suatu masyarakat yang selalu saling berinteraksi, di pedalaman atau pedesaan memiliki sistem tata ruang yang baik, dikarenakan mereka memiliki sebuah norma atau tata aturan tentang tata ruang dan dampak ekologis terhadap kelangsungan hidup mereka. Pada masyarakat pedalaman, mereka memiliki sebuah folkor (sistem kepercayaan) tentang keselarasan antara ruang dan 
kehidupan. Mereka meyakini bahwa sebuah desa yang memiliki jarak antar rumah yang cukup dan sistem irigasi serta pembuangan yang memadai akan mendukung proses kehidupan mereka dengan baik. Hal ini yang membentuk sebuah nilai dalam prose kehidupan mereka, bahwa tata ruang yang baik akan menciptakan suatu kehidupan yang selaras dengan alam.

Homogenitas kesamaan nilai dalam membentuk sebuah tata ruan,masyarakat pedesaan pada umunya memiliki kesamaan kepentingan dalam membentuk sebuah pola tata ruang desanya,ini dikarenakan mereka memegang satu nilai tentang hal ekologi dan efek kelangsungannya terhadap kehidupan,hal tersebut membentuk suatu pola pikr umum tentang bagaimana seharusnya tata ruang yang baik bagi desa mereka. Sebagai hasilnya, dapat kita lihat kerapihan yang ada di desa, sebagai contoh perumahan adat di tanah batak, yang tersusun rapi oleh karena sistem kepercayaan yang sama di pola pikir mereka.

Tidaklah dapat disangkal akan adanya pengaruh kebudayaan terhadap perwujudan adanya ruangan (space) dimana hubungan-hubungan antar individu dapat diwujudkan dengan tepat sesuai dengan motif dan lingkungan yang dihadapi oleh yang bersangkutan. Hall (1959) telah menunjukkan bagaimana pentingnya peranan pengetahuan tentang kewilayahan (territoriality) yang dipunyai oleh hewan juga terdapat pada manusia dalam wujud jarak (distance), yang bagi manusia sebenarnya merupakan medium komunikasi di antara sesamanya. Dalam tulisan tersebut lebih lanjut ditunjukkan oleh Hall bahwa kebudayaan merupakan landasan bagi terwujudnya pola-pola mengenai tata ruang yang ada pada arsitektur, tata ruang pada umumnya (landscaping), dan pada desain tata kota.

Dalam studinya lebih lanjut mengenai ruang sebagai suatu dimensi yang tersembunyi dalam kebudayaan manusia, Hall (1966) memperlihatkan bahwa manusia hidup dalam ruangan-ruangan dengan tipe-tipe dan ukuran-ukuran tertentu yang tepat sesuai dengan kebudayaan mereka masing-masing. Salah satu dari ruangan-ruangan dimana manusia hidup dan memperlihatkan adanya tipe dan ukuran yang tertentu adalah rumah (berikut pekarangannya) tempat manusia tinggal. Struktur sosial dan tata ruang dalam kebudayaan di Indonesia sangat beraneka ragam, penduduk Indonesia yang tersebar di desa-desa, kampung-kampung yang di atur dalam tatanan budaya lokal dalam bentuk pola tata ruang sosial budaya berdasarkan pada nilai dan tradisi pada masing-masing etnik.

Suku di Papua rata-rata memiliki struktur sosial dan tata ruang kebudayaan beraneka ragam yang berperan penting dalam kehidupan sosial dan budaya mereka. Sistem yang mengatur hubungan atau relasi antar warga dalam berbagai aktivitas hidupnya sehari-hari berdasarkan kebudayaan mereka masing-masing, yaitu sistem politik atau sistem kepemimpinan politik tradisional. Sistem politik tradisional yang dikenal oleh orang Papua ada empat sistem atau tipe kepemimpinan politik. Ke-empat sistem atau tipe kepemimpinan tersebut yaitu (1) Sistem Kepemimpinan Bigman atau Pria Berwibawa, (2) Sistem Ondoafi, (3) Sistem Kerajaan, dan (4) Sistem Campuran. (Mansoben, 1985).

\section{Metode}

Jenis penelitian ini adalah deskriptif dengan pendekatan etno metodologi studi lapangan. Penelitian dilakukan di Distrik Yokari pada kebudayaan suku bangsa 
Yokari Kabupaten Jayapura Provinsi Papua. Informan Penelitian berjumlah 15 orang yang dipilih secara purposive yaitu para ondoafi kepala etnik, para oandoafi kepala klen, tua tua adat di lima kampung, Dewan adat Etnik Yokari. Tua tua klen suku bangsa Yokari. Fokus penelitian bagaimana struktur sosial dan tata ruang dalam kebudayaan suku bangsa yokari, berkaitan dengan empat kelompok klen menguasai dan memanfaatkan ruang-ruang sosial budaya baik ruang darat, ruang laut dan ruang udara. Metode Pengumpulan data dilakukan melalui dua cara yaitu observasi dan wawancara mendalam (indepth interview) untuk mendapatkan data primer. Sedangkan untuk data sekunder yaitu dengan melihat dokumentasi tentang data-data dan laporan yang berkaitan dengan suku bangsa Yokari.

Analisa data kualitatif adalah proses mencari dan menyusun secara sistimatis data yang diperoleh dari hasil wawancara, catatan lapangan dan bahan-bahan lain sehingga mudah dipahami dan temuannya dapat di informasikan kepada orang lain. Dalam penelitian ini analisa data dilakukan setelah data diperoleh dan berlangsung sejak pengambilan data dimulai (ongoing analysis).

\section{Pembahasan}

\subsection{Struktur Sosial Budaya Suku Bangsa Yokari}

Struktur sosial diartikan sebagai hubungan timbal balik antar posisi sosial dan antar peran. Struktur sosial juga merupakan suatu tatanan sosial dalam kehidupan masyarakat yang di dalamnya terkandung hubungan timbal balik antara status dan peran dengan batas-batas perangkat unsur-unsur sosial yang menunjuk pada suatu keteraturan perilaku, sehingga dapat memberikan bentuk sebagai suatu masyarakat. Soerjono Soekanto (2002:68) Struktur sosial merupakan suatu pergaulan hidup manusia meliputi berbagai tipe kelompok yang terjadi dari banyak orang dan meliputi pula lembaga-lembaga dimana orang banyak tersebut ambil bagian Raymond Flirth (1985:78).

Struktur sosial orang Yokari terdiri atas kesatuan-kesatuan sosial berupa klen (marga) dan komunitas kampung. Dalam budaya orang Yokari setiap klen mempunyai fungsi-fungsi tertentu. Pembagian klen berdasarkan fungsi-fungsi tertentu bertujuan untuk menjaga dan mempertahankan struktur sosial (A.R. RetlifBrown, 1952).

Terkait dengan struktur sosial suku bangsa Yokari bahwa mereka terbagi dalam empat kelompok besar, yaitu kelompok Kaniyo, Yowari, Yepei dan Yepei Yowari, masing-masing mempunyai tugas dan fungsi untuk mengatur dan menata kehidupan sosial mereka berdasarkan norma-norma yang ada. Kelompok-kelompok ini juga menguasai wilayah-wilayah tanah adat, wilayah laut sebagai warisan leluhur dalam berbagai aktivitas kehidupan yang berkaitan erat dengan mata pencaharian hidup, disamping itu Ondoafi adalah sebagai penguasa tertinggi atas lingkungan wilayah kehidupan mereka yang diatur dengan tatanan serta kaidah- kaidah adat yang berlaku untuk mengatur berfungsi sebagai pelindung. Suku bangsa Yokari terbagi dalam empat kelompok dan dipimpin oleh seorang Ondoafi yang berkuasa atas klen dan marga. Ondoafi adalah puncak tertinggi dari kepemimpinan suku-bangsa Yokari. Ondoafi dapat dipilih dari keturunan kaniyo, dan keturunan Yowari atau Yepei, tergantung dari kekuatan dan kesiapan, serta ditunjang oleh prestasi yang baik dan kemudian dinilai oleh masyarakat bahwa yang bersangkutan layak untuk dinobatkan sebagai Ondoafi pada kampung tersebut. Tingkat strata teratas dalam suku bangsa 
Yokari adalah Ondoafi yang juga adalah anak sulung dalam kelompok klen marga tersebut, juga kerabat dan keluarga adik-adik Ondoafi yang mempunyai hubungan keturunan satu darah disebut keluarga Ondoafi. setelah Ondoafi sebagai pemimpin tertinggi, strata berikut adalah Pesuru sebagai menteri yang bekerja dalam pemerintahan Ondoafi. Kemudian strata terakhir adalah masyarakat yang terdiri dari keturunan tengah dan turunan yang terakhir dalam kampung tersebut.

Struktur sosioal suku bangsa Yokari berada di wilayah kebudayaan Mamta. Ada beberapa konsep struktur sosial yang dapat kita simak memiliki sedikit perbedaan dalam kebudayaan yang ada di wilayah Tabi, misalnya, pada tipe budaya Etnis Find di Senggi, ada beberapa aspek yang saling berkaitan antara sumber dari leluhur yang sama, prinsip keturunan (decent principle) dan prinsip teritorial tidak dapat dipisahkan dari hak-hak dan kewajiban mereka akan tanah dalam berbagai fungsi (dusun sagu, sungai, wilayah berburu, dan sebagainya). Prinsip keturunan dan prinsip teritorial kemudian disatukan ke dalam sistem perkawinan. Fungsi multi dari kelompok-kelompok keturunan dan kelompok-kelompok garis keturunan (lineage group) kadang membuat sukar mendefinisikan secara ketat akan batas-batas kekerabatan dan wilayah secara politik. Kelompok etnis Find membagi itu lebih berdasarkan kisah tentang migrasi mereka, perjalanan leluhur wilayah-wilayah adat dan pengelompokan-pengelompokkan kekerabatan (clan) yang didasarkan oleh sejarah, kesamaan adat dan wilayah teritorium tertentu.

Terjadinya struktur sosial di dalam masyarakat sebagai akibat dari adanya proses pertumbuhan masyarakat berlangsung secara alamiah. Namun ada pula struktur sosial yang dibentuk dengan sengaja untuk mencapai suatu tujuan bersama. Pada struktur sosial yang terjadi secara ilmiah biasanya terbentuk atas dasar kepandaian, tingkat umur, sifat keaslian keanggotaan kerabat seorang kepala masyarakat, dan juga mungkin harta dalam batas-batas tertentu. Struktur sosial ini mempunyai keeratan yang kuat sehingga bentuk ini tidak menimbulkan kerawanan konflik di dalam masyarakat. Karena terjadi secara ilmiah struktur sosial ini tidak memiliki orientasi tertentu dan juga sudah menjadi kesepakatan di masyarakat.

Puncak pencapaian gelar dari Ondoafi pada suku bangsa Yokari adalah "Yerang”. Untuk mencapai "Yerang", Ondoafi harus membuat "Metau" atau upacara pengukuhan atas dirinya oleh persetujuan "wero, yaro", dan "Touna Yarise-yarise" dalam klen-klen suku bangsa Yokari atas dasar pertimbangan-pertimbangan dan kelayakan, penilaian terhadap kemampuan individu, kemampuan, matapencaharian, atau kekuatan ekonominya, kekuatan dan dukungan dari keluarga, mampu menunjukan pelayanan dengan baik, dalam istilah lokal adalah tungku apai selalu minyala, selalu melayani tamu dengan baik, berkata-kata dengan baik, berperilaku baik dalam kampung, pendamai,peramah, menghadiri pesta adat atau pesta upacara kematian di kampung dan di luar kampung, semua ini menjadi kriteria untuk di nobatkan dengan pangkat yerang.

Ondoafi dalam bahasa Yokari adalah sebuah gelar yang diberikan kepada garis keturunan yang tertua "Yarise " pada klen-klen atau marga pada suku bangsa Yokari. Ondoafi adalah pemimpin atas marga itu sendiri dan pemegang kekuasaan atas marga yang ada dalam satu kampung, kepemilikan hak kepemimpinan merupakan hak warisan turun temurun, hak "ondoafi" tidak bisa diberikan kepada garis keturunan lain yang tidak ada garis aliran darah, hanya dapat diberikan kepada 
turunan yang tertua "Yarise" yang memiliki garis keturunan satu aliran darah, atau juga turunan yang berikutnya dari satu Tete.

Tugas dan fungsi Ondoafi dalam melayani pekerjaan dalam keluarga, menjaga keluarga, mengarahkan keluarga untuk mentaati norma dan aturan-aturan adat, melakukan tugas-tugas kemanusiaan, seperti menolong keluarga dalam kelen dalam bentuk kerja, ataupun memerintah membantu keluarga jika ada keluarga yang mengalami musibah atau meninggal, atau membantu mendukung keluarga bekerja dalam bidang mata pencaharian hidup, dilaut, didarat, mengambil keputusan seadiladilnya dalam menyelesaikan sebuah pertikaian dalam klen atau diluar klen, mendoakan bagi keberlangsungan kesuburan tanah pertambahan keturunan kehidupan dan keselamatan klen tersebut.

Dalam kepemimpinan Ondoafi ada pendamping yang diambil dari keluarga dekat dalam marga itu juga masi satu aliran darah moyang sebagai pendamping atau "Tekai" dan bertugas untuk melakukan tugas Ondoafi. Bilamana ketika "Ondoafi" ada kesibukan lain atau keluar kampung tidak menjalankan tugas, Tekai akan mengambil kendali pemerintahan sementara untuk memerintah, menghadiri semua kegiatan yang berkaitan dengan adat. Tekai juga merupakan pendamping yang di persiapkan sebagai pengganti keturunan ondoafi apabila dalam perkembangan generasi dan turunan tidak ada anak laki-laki yang mewarisi maka Tekai yang boleh menggantikan posisi itu. Akan tetapi tidak serta merta, dia harus melewati tahapan proses seperti Ondoafi sebelumnya. Pesuru atau "wero" akan melihat loyalitasnya, keterbukaannya, dan juga dia memiliki jiwa sosial tinggi, selalu memberi, menolong sesama klen bahkan di luar klen tersebut, barulah diangkat menjadi Ondoafi, menggantikan yang sudah pernah ada, apabila Tekai kurang memenuhi persyaratan tadi, maka akan dipilih turun tersebut urutan berikut yang dianggap berloyalitas tinggi untuk dingkat menjadi Ondoafi.

Pada kepemimpinan "Ondoafi" terdapat Pesuru yang melakukan tugas- tugas dalam rumah dan diluar rumah dalam kelen tersebut, petugas yang bekerja dalam rumah ondoafi disebut Yaro meeuna "Yaro sena" menjaga aktivitas hidup keluarga "Yarise" atau "Ondoafi" mengantur segalah sesuatu yang berkaitan dengan persiapan upacara adat dari Ondoapona, menentukan upacara itu dapat terlaksana atau tidak, juga menilai prestasi kerja atau loyalitas dari anak sulung "Yarise" tersebut, sedangkan "yaro" bagian luar bekerja mempersiapkan kelompok klen untuk mengumpulkan bahan makanan baik didarat ataupun dilaut dan menyiapkan meja atau batu lingkaran "Orudia," untuk Ondoafi yang akan berbicara di batu lingkaran tersebut setelah dilantik, kalau batu lingkaran telah ada dan hanya melanjutkan berarti, hanya menyiapkan pelantikan yang berkaitan dengan persiapan lain.

Tingkat kesatuan sosial suku bangsa yokari sebagaimana terbagai dalam empat bagian yaitu Kaniyo, Yepei, Yowari, dan Yepei Yowari, dan masing-masing keempat bagian ini memiliki hubungan sejarah asal-usul garis keturunan dan kekerabatan yang di dasarkan atas norma-norma kaidah-kaidah adat yang mengatur hubungan kehidupan sebagai control sosial mereka.

Kesatuan hidup manusia yang berinteraksi menurut suatu sistem adat istiadat tertentu yang bersifat kontinyu, dan yang terikat oleh suatu rasa identitas bersama. Koentjaraningrat (2002:146) masyarakat itu saling mempengaruhi satu sama lain, di mana saling berhubungan tingkah laku dan perbuatan yang dilandasi oleh suatu 
kaidah dan siapa yang melanggarnya akan diberi sanksi sesuai dengan ketentuannya. (Cholil Mansyur:137)

Kesatuan tingkat etnik meliputi, keseluruhan kelompok suku bangsa Yokari. Kesatuan ini terbagi dalam lima kampung, yaitu: kampung Bukisi, kampung Meukisi, kampung Endokisi, Kampung Demoikisi, Kampug Buseryo. Kesatuan etnik ini kemudian terbagi kedalam empat kelompok besar yaitu; kelompok klen Kaniyo, kelompok klen Yowari, kelomopk klen Yepei dan Kelompok Klen Yepei Yowari. Dari kesatuan tingkat etnik ini dalam sitim kepemimpinan atau sistim politik tradisional, puncak pencapaian kepemimpinan tradisional adalah Yerang. Yerang adalah merupakan gelar tertinggi. Pemimpin berikut dibawah yerang adalah Ondoafi. Pemimipin tertinggi Yerang mempunyai "Wero" "Yaro" sebagai pesuru atau menteri, pekerja tersebar di lima kampung yang ada di wilayah suku bangsa Yokari, dan mereka mempunyai tangung jawab terhadap kepemimpinan Yerang dalam pelaksanaan kegiatan adat. Kesatuan tingkat etnik ini juga mempunyai dua "Orudia" meja adat terbesar yaitu meja adat, "Demoi-dia dan "Waring-dia " dan kedua meja adat tersebut mempunyai sistim kerjasama untuk keperluan pemerintahan, berkaitan dengan adat istiadat dan hubungan sosial lainnya.

Kesatuan sosial setiap kampung yang ada di wilayah suku bangsa Yokari adalah kampung tradisional yang terbagi kedalam dua sampai tiga kesatuan besar berdasarkan asal mula marga itu berada dan juga tergolong dalam empat kelompok besar yaitu; kelompok Kaniyo,Yepei, Yowari, dan Yepei Yowari. Misalnya pada kampung Demoikisi terbagi dalam dua kampung adat, berdasarkan kampung tua mereka. Kampung "demoiyo" adalah kampung yang secara adat sejak awal berada di atas gunung. Jumlah kelompok marga yang berada dalam kampung "demoiyo" adalah, marga Kwasuna, maraga Yumilena, marga Taplamilena Yarisetouw, Marga Takaitouw, Marga Ondoafo Matiseray, Soning deme, marga Ortumilena, marga klorway, kampung ini mempunyai dua batu lingkaran "oru nukuway”,pada marga Ondoafo Matiseray dan "oru kreume” begitu pula kampung "mangsangyo", juga sejak awal berada diatas gunung kemudian mereka turun kelembah pinggiran garis pantai, dan menempati wialayah kampung adat mereka tersebut, kelompok marga yang menempati kampung Mangsangyo adalah; wafumilena, Yaroseray, Kespo,Oyai Yarisetouw. Dalam kesatuan kampung mangsangyo, ada dua batu ligkaran adat yaitu pada maraga wafumilena "Oru Simiyei" dan pada marga Yaroseray "Oru Yeramai"

Kesatuan tingkat klen pada suku bangsa Yokari adalah terdiri dari kelompok kelompok marga yang tersebar di masing-masing lima kampung yang ada, dan masing-masing marga tersebut, tergolong dalam satu kelompok besar yang disebut Kanyo,Yepei,Yoeri atau Yepei Yowari dan mempunyai pemimpin keluarga yang disebut "tou yarise" anak sulung dalam keturunan marga tersebut, dan bertangung jawab secara moral terhadap keluarga, dalam berbagai aktivitas adat baik dalam tingkat klen dan juga tingkat kampung, lebih luas adalah tingkat etnis. kelomopok klen ini masih berada secara turun temurun berasal dari satu moyang, atau leluhur, dan kemudian berkembang secara revolusi hingga menjadi kleompok kelen besar.

Pada umumnya baik kelompok kesatuan etnik, kelompok kesatuan kampung dan kelompok kesatuan klen dalam kebudayan suku bangsa yokari, memmiliki norma dan aturan-aturan yang sama baik itu aturan tentang hak dan kewajiban ondoafi. Aturan tentang hak ulayat, aturan tentang religi, aturan tetang mata pencahrian, dan aturan tentang tangung jawab warga terhadap adat serta norma-norma adat sebagai 
control sosial, pada umumnya sama, dan berlaku, baik secata tingkat etnik sampai tingkat klen.

\subsection{Struktur Tata Ruang Sosial Budaya Suku Bangsa Yokari}

Ruang adalah wadah yang meliputi ruang darat, ruang laut, dan ruang udara, termasuk ruang di dalam bumi sebagai satu kesatuan wilayah, tempat manusia dan makhluk lain hidup, melakukan kegiatan, dan memelihara kelangsungan hidupnya (Pasal 1 ayat 1; UU No. 26/2007 tentang Penataan Ruang-Revisi terhadap UUPR No. 24/1992). Ruang terbuka hijau adalah area memanjang/jalur dan/atau mengelompok, yang penggunaannya lebih bersifat terbuka, tempat tumbuh tanaman, baik yang tumbuh secara alamiah maupun yang sengaja ditanam (UU No. 26/2007 tentang Penataan Ruang). Suatu wadah yang menampung aktivitas manusia dalam suatu lingkungan yang tidak mempunyai penutup dalam bentuk fisik (Budihardjo, 1999; 90).

Berkaitan dengan ruang sebagai wadah, maka dapatlah kita lihat pada hasil penelitian di lapangan bahwa Suku bangsa Yokari adalah kelompok etnik yang juga memiliki dan menempati ruang kebudayaan mereka yang menjadi hak ulayat yang terdiri dari ruang darat, ruang laut dan ruang udara termasuk ruang di bawah tanah. Ruang-ruang suku bangsa Yokari tersebut dikuasai oleh beberapa kelompok klen yang menurut sejarah mitologi asal-usul adalah kelompok klen pertama yang menempati ruang sosial budaya tersebut. Kelompok klen-klen yang berkuasa atas ruang-ruang tersebut adalah; kelompok klen Kaniyo, sebagai kelompok pertama dan klen Yepei sebagai Kelompok kedua, dan kelompok Yowari adalah kelompok ketiga serta kelompok ke empat adalah gabungan peran antara kelompok Yepei dan Kelompok Yowari yang juga menguasai ruang-ruang sosial budaya. Kelompok klen Kaniyo menguasai ruang darat diantaranya tanah, hutan, tanah pemukiman, ruang bawah tanah, ruang laut, ruang udara, berkaitan dengan, mata pencaharian hidup sebagain klen pertama. Kelompok klen Yepei menguasai ruang tanah, ruang laut, ruang udara dan lebih berorientasi kepada sistem pemerintahan dan pengamanan, sebagai kelompok kedua yang lahir dari kelompok Kaniyo. Kelompok Yowari, menguasai ruang darat, laut, udara, dan ruang di dalam tanah, tetapi berhubungan dengan religi, berkaitan dengan jalur-jalur sumber ekonomi berkaitan dengan mata pencaharian hidup sebagi kelompok pemilik ketiga dari klen Kaniyo, dan lebih berorientasi pada spiritual dan perkembangan generasi dalam keharmonisan dan penyelesaian sengketa dan perbaikan hubungan kekeluargaan, juga sebagai pengontrol semua aktivitas mata pencaharian hidup.

Ruang sosial budaya yang ada dalam kebudayaan suku bangsa Yokari, sudah diberikan kepada masing masing empat klen dan menjadi tanggungjawab mulai dari menjaga mengelola, dan memanfaatkannya. Ruang darat dengan segala makluk hidup yang ada, ruang laut, ruang dibawah tanah, dengan semua makluk hidup dan tumbu-tumbuhan diatur dalam norma-noma adat yang jelas sebagai kontrol sosial dalam mengendalikan ruang-ruang tersebut.

Ruang menjadi bagian tak terpisahkan dalam aktivitas sehari-hari. Ruang terbentuk dari pengalaman yang secara langsung dirasakan dalam bentuk tiga dimensional dengan bantuan indra penglihat (Tuan, 2010:12). Pengalaman terkumpul menjadi ingatan dan cara tertentu untuk merasakan ruang. Karakter manusia dan kebudayaan membentuk pola aktivitas dan pemaknaan sebuah ruang. Karakter yang kuat dari budaya akan menciptakan ruang dengan identitas khas sehingga dapat dirasakan 
sebuah place (Trancik, 1986:112). Place terbentuk dari pengalaman masa lalu yang dikontruksikan kembali oleh serangkaian indra (penglihatan, pendengaran, penciuman, dan indraperasa) sehingga ruang memiliki makna tertentu. Ruang hanya akan menjadi hidup ketika manusia memberikan makna pada tempat, aktifitas emosional dan perasaan atraktif yang terkombinasi menjadi pengalaman dan interaksi di dalam sebuah ruang (Paker, 2012:159). Elemen ruang menjadi unsur penting dalam menciptakan makna, salah satu bahasa komunikasi untuk memaknai ruang adalah budaya (cultural code) (Rapoport, 1982:50).

Demikian pula dalam budaya suku bangsa Yokari, struktur sosial terbentuk dan terbagi dalam empat kelompok besar yang diatur oleh nilai-nilai dan norma kaidahkaidah serta pranata-pranata adat sebagai media pengontrol kehidupan suku bangsa Yokari. Tugas dan fungsi-fungsi dalam adat ini berkaitan erat dengan ruang-ruang budaya sebagai tempat-tempat utama baik untuk mata pencaharian hidup yang diperuntukan untuk berkebun, berburu, permukiman menangkap ikan. Dalam berbagai peran dan fungsi masing-masing klen yang berhak memiliki dan berhak menguasai dan memanfaatkanya, ada klen yang berperan pengatur pemanfaatan ruang darat, ruang laut, dan juga, ruang udara, semua ini dilakukan berdasarkan struktur keturunan dan pewarisan yang jelas dan tidak menyimpang dari struktur keturunan tersebut.

Pusat pusat pemukiman suku bangsa Yokari zaman dahulu rata rata berada diatas gunung. Setiap kelmopok klen-klen ini menempati kampung masing-masing dengan nama tersendiri, kemudian mereka turun kelembah dan menetap di lemabah di pinggir garis pantai wilayah kekuasaan suku bangsa yokari sendiri dan membagai tempat-tempat pemukiman sesuai dengan kelompok klen mereka. Dalam pusat pusat pemukiman suku bangsa Yokari di terdapat seorang pemimpin yaitu tou Yarise atau anak sulung dalam keluarga tersebut, yang secara langsung berkuasa mengatur kehidupan sosial mereka dibantu oleh pesuru (wero,yaro) memiliki tanggung jawab yang diatur dalam norma tatanan adat mereka. Sarana prasarana yang digunakan untuk mengatur kehidupan mereka kelompok klen-klen suku bangsa Yokari seperti: Rumah adat (ongko miye), yang merupakan tempat yang berfungsi untuk pembinaan dan fungsi religi. Ada batu lingkarang (oru dia) sebagai meja adat untuk fungsi musyawarah dan fungsi religi.

\subsubsection{Ruang Darat}

Pengaturan dan pemanfaatan ruang sosial budaya, oleh masyarakat tradisional sudah berlangsung sejak manusia menempati bumi. Mengatur tempat hidupnya dan bermukim adalah upaya untuk mempertahankan hidup agar terhindar dari gangguan alam dengan cara berpindah-pindah (nomaden) dari satu tempat ketempat yang lain, serta memanfatkan potensi hasil alam sekitar untuk keberlangsungan hidup. Mengatur dan memanfaatkan alam di Indonesia khususnya di provinsi papua, hampir 85\% masyarakat papua masih mengatur dan memanfaatkan alam sesuai dengan wilayah hak ulayat mereka masing-masing untuk mempertahankan hidupnya. Lingkungan dimana mereka tinggal adalah bagian dari hidup kehidupan mereka dan mereka harus menyesuaikan dengan kondisi geografis setempat.

Ruang darat yang teridiri dari Tanah yaitu Gunung Perbukitan dan lembah,menjadi hak milik ulayat klen kaniyo,Yowary,Yepei dan Yepei Ywari,dalam marga-marga yang ada dalam kelompok suku bangsa yokari, dengan batas-batas kepemilikan yang jelas secara turun temurun. Tanah memegang peranan penting dalam kehidupan suku 
bangsa Yokari sehingga mereka menyebut tanah sebagai seorang Ibu (nawa) konsep tentang tanah adal selalu memberikan hasil yang baik lewat tumbuh-tumbuhan, yang dapat di konsumsi bagi masyarakat dalam suku bangsa yokari. Tanah tidak boleh di jual, tanah harus di ibahkan, atau di barterkan, karena tanah seperti seorang perempuan yang diberikan kepada pihak laki-laki dan akan mengembagkan keturunan bagi orang laian. Di dalam tanah juga berdiam leluluhur-leluhur penjagapenjaga pintuh sumber ekonomi, yang selalu memberikan penghasilan-penghasilan berupa hasil-hasil di alam, seperti hutan, hewan dan hasil kebun dan lain-lain.

Pengaturan tanah suku bangsa Yokari, tanah dalam pengaturannya, mereka telah melakukan pembagian atau pemberian tanah sudah sejak dahulu, pemilik tanah oleh kelompok Kaniyo membagikan kepada kelompok Yepei dan klompok Yowari, untuk dimanfaatkan untuk berkebun dan mengambil hasil lain dari alam tersebut. Tanah dalam masing-masing klen marga dikuasai oleh Touna Yarise dan kemudian diberikan kepada saudara laki-laki atau saudara perempuan. Tanah pemukiman tempat tinggal pun telah diatur untuk semua klen dan satu marga itu dapat membuat rumah secara bersama berkeompok dan areal yang menjadi hak milik marga tersebut. Semua kelompok marga jika hendak membuat rumah baru harus melaporkan kepada Touna Yarise atau anak sulung sebagai pemimpin dalam keluarga, setelah mendapat ijin persetujuan barulah yang bersangkutan dapat membuat rumah. Dalam pembuatan rumah di tanah area pemukiman, tentu harus memperhatikan ruang areal tempat rumah. Ondoafi arealnya harus besar, karena areal rumah Ondoafi selalu ditempati "oru dia" atau meja adat tempat musyawarah dan pesta-pesta adat.

Secara umum batu lingkaran atau "Orudia" yang da di suku bangsa Yokari, fungsinya membahas dan menyelesaikan serta memberi sangsi atas masalah-masalah yang terjadi dalam kehidupan sosial dan budaya masyarakat setempat, namun ada bentuk penyelesaian masalah dlam lingku yang kecil misalnya masalah itu di bahas di batu lingkaran swai oru, kemudian telah mendapat kata sepakat, dan maslah itu menjadi rekomendasi untuk dibahas di batu lingkaran besar untuk memutuskannya, ini berlaku untuk klen Kaniyo,Yowari, Yepei, dan Yepei Yowari.

Posisi letak batu lingkaran selalu berada tepat di halaman depan rumah ondoafi atau Touna Yarise, dan tidak boleh berada dihalaman rumah orang lain ataupun halaman saudara adiknya, ataupun di belakang rumah, karena berlawanan dengan, harkat jatidiri dari seorang ondoafi yang harus dijaga, dan menjadi perhatian penting bagi keluarga kerabat, dan juga menjadi panutan bagi keluarga dan klen, apabila terdapat batu lingkaran di depan ruamah seseorang itu berarti ondoafi atau rumah "Touna yarise" secara tidak langsung ada hukum yang mengatur lingkungan tersebut, dan tidak bola disengaja atau di langgar oleh orang lain atau klen lain.

Hutan Sonasi (dari-sena) hutan lebat yang menjadi hutan larangan yang belum disentu oleh manusia di tumbuhi pepohonan yang besar secara alami, sedangkan hutan tempat berkebun yang berdekatan dengan hutan dari-sena adalah hutan (darimikan), hutan yang tempat diman mereka menanam dan berkebun, dan letaknya kurang lebih 10 kilometer dari lokasi pemukiman, dan hutan pinggiran pemukiman (miski) hutan tempat berkebun dengan jarak satu kolometer sampai lima kilo meter. Hutan-hutan tersebut di kuasai oleh masing-masing kelompok-kelompok pemilik hak ulayat secara turun temurun sedangkan konsep ruang tempat permukiman,suku bangsa yokari adalah tempat dimana suku bangsa yokari mendirikan rumah secara berkelompok dan menurt klen dan marga masing masing. Semua tempat permukiman 
ini adalah merupakan tempat warisan leluhur mereka ketika pertama kali bermukim dan membuat rumah ditempat tersebut maka akan dilanjutkan oleh generasi berikut untuk membuat rumah di tempat tersebut.

Berkebun diatur oleh kepala klen atau touna yarise. Membagikan lahan hutan milik klen untuk digunakan berkebun dan menanam tanaman jangka panjang, batas, semua lahan hutan berkebun ini sudah dibagikan kepada keluarga dari yang tertua samapai yang terakhir, mereka akan terus berkebun dilahan tersebut dan menanam tanaman jangka panjang,. pembagian ini sudah menjadi bagian yang sah untuk menjadi hak pakai seam generasi ganti generasi. aturan aturanadat yang mengikat dan menagtur hutan tersebut dan tidak boleh klen lain merampas hutan milik klen lain, jika perampasan terjadi akan terjadi perang atau perkelahian, atau dihukum dlam keputusan adat lewat kesepakatan diatas batulingkaran "oru-dia" sangksi lain adalah sangksi supranatural, dalam bentuk yang bersangkutan akan sakit dan kemudian meninggal.

\subsubsection{Ruang Laut}

Wilayah laut dalam pengaturannya diatur oleh kelompok yepei yang dianggap memiiki pengetahuan tentang laut, buai dari terumbuh karang hingga laut lepas. kelompok klen yang mempunyai pengetahuan tentang laut pada suku bangsa yokari adalah, klen Mandowali, klen kesepo, klen demena, oyaitou, dan klen taplamilena yarisetouw, klen matiseray ondoafo. kelompok klen ini mengetahui terumbuh, karang yang merupakan sarang ikan dan kerang mulai dari pinggiran pantai, tanjung hingga laut lepas. semua areal terumbuh karang ini dapat di manfaatkan untuk mengambil ikan di tempat tersebut, dan masing-maing terumbuh karang tersebut, mereka telah mengetahui nama-nam tersebut,. untuk mengambil hasil laut tersebut semua klen adapat mengambilnya dengan cara yang benar sesuai dengan ketentuan adat, jika mengambil hasil dengan cara yang tidak benar sesuaidengan ketentuan adat akan mendapat sangsi adat. kelompok yang mempunyai pengetahuann tentang laut ini mereka juag bertugas untuk menutup areal pencaharian dilaut dengan cara mensasi (Tiatiki) bentuk pelarangan yang dilakukan untuk beberapa waktu lamanya kemudian di buka dan mereka semua beramai, ramai mengambil hasil area laut ini.

Tiatiki juga bukan hanya untuk wilayah laut semata tetapi berlaku bagi wilayah daratan, misalnya pada tumbuh-tumbuhan, pohon kelapa, pohon kayu, buah buahan, jangka waktu 5-10 tahun Setelah penyampaian ini para tua-tua adat akan kumpul pada malam hari di rumah adat Ondoafi atau di halaman batu libgkaran, mereka melagukan lagu wari-wari bersyair kedamaian di iringi pikulan atau ketukan tifa yang diyanyikan untuk memuja tuhan semesta alam dan semua kekuatan alam sekitarnya, dalam lagu ini adalagu yang mengandung kekuatan gaib, tidak dapat di mengerti oleh orang lain, lagu itu hanya dinyanyikan oleh Ondoafi, setelah sampai pagi barula mereka meng Tiatiki tempat atau reef tersebut dengan menancap batang pohon pada terumbuh karang sesuai dengan kesepakatan waktu yang di tentukan, (Yarisetouw Wiklif, 2009)

Maka dalam pengaturan dan memanfaatkan ruang laut adalah sebagai tempat mata pencaharian hidup sejak dahulu. Klen yang menguasai ruang laut adalah klen "wanya oko", karena sejak awal kelompok klen ini yang lebih banyak dalam mata pencaharian hidup orientasinya melaut sehingga mengetahui terumbu karang atau tempat dimana ikan di dasar laut mulai dari timur sampai ke barat. "wanya oko" sebagai klen pertama yang berperan sebagai pelaut yang menggunakan saran 
transportasi laut berupa perahu dayung atau perahu lesung bercadik yang dilengkapi dengan Alat-alat untuk penangkap ikan seperti tombak (kalawai), tali pancing (nilon) dan (kail), juga akar tuba untuk meracuni ikan,

Pada hasil wawancara berkaitan dengan aktivitas mata pencaharian hidup di laut, ada beberapa pengetahuan melaut yang di miliki dengan peralatan sederhana, seperti memgunakan kail, tomabak dan tuba. Aktivitas ini dilakukan pada musim cuaca yang baik air laut teduh antar bulain mei sampai julli. Aktivitas menangkap ikan dengan cara meracuni ikan dengan menggunakan tuba, proses ini dilakukan di areal terumbuh karang dan pinggiran pantai.roses merancuni ikan biasanya diawali dengan Upacara penutupan terumbu karang di areal laut depan kampung dengan istilah "Tiatiki" atau sasi pelarangan areal laut agar biota laut, berupa ikan dan kerang berkembang. Penutupan areal laut ini terjadi kurang lebih enam bulan hingga satu tahun, kemudian diadakan upacara membukaan larangan sesuai waktu yang ditentukan lalu semua klen di libatkan bersama-sama mengambil hasil tersebut.

Untuk melakukan aktifitas laut pada suku-bangsa Yokari tidak bisa terlepas dari kelompok pemegang kunci sumber berkat yaitu kelompok "Kaniyo" dan "Yowari", karena semua mantra yang berkaitan dengan jenis mata pencaharian hidup mereka menguasainya, meskipun klen lain juga mempunyai keahlian dalam menangkap ikan dilaut, Konsep tata ruang laut suku bangsa yokari, adalah wilayah kekuasaan yang terhitung mulai dari garis pantai hingga batas pandangan mata kearah laut lepas, daerah pingiran pantai disebut (kisika) hingga kelaut lepas sebagai areal untuk mata pencaharian hidup yang di kuasai oleh kelompok suku yang menguasai laut juga terdapat dalam empat kelompok besar Kaniyo, Yowari, Yepei dan Yepei Yowari, dari empat kelompok, ada beberapa klen yang menguasai laut, seperti klen wanya oko, klen taplamilena yarisetouw, klen kesepo, penguasaan laut terhitung mulai dari garis pantai, terumbuh karang yang dekat hingga terumbuh karang yang terjauh dlam batas pandangan mata. Pemanfatan laut derah pengiran pantai terumbu karang di manfaatkan setiap musim untuk mengambil hasil laut, dan manfaatkan untuk membuat sasi pelarangan dengan jangka waktu tertentu agar biota laut berkembang dan kemudian dilakukan pembukaan sasi serta panen hasil bersama. Tanjung (yemo) adalah sebagai pembatas bagi wilayah laut antara kampung atau suku-bangsa yang satu dengan yang lain.

Mereka juga mempunyai pengetahuan mengatur pembagian wilayah laut dan pesisir dengan berapa suku kelompok suku-bangsa tetangga seperti suku bangsa "Tepera" dan "Yewena, Wari dan Sow". Pembagian wilayah laut pesisir lokal suku bangsayokari adalah sebagagai berikut;

1. Akadame, yaitu bagian wilayah laut yang dihitung jarak mulai dari batas surut air laut, sampai dengan batas air pasang dan di kedalaman kurang lebih dua belas meter

2. Kia-kia adalah bagian laut yang memiliki kedalaman 12 meter sampai 25 meter, dalam pandangan mata dasar laut nampak terlihat dari atas tersebut, jika kita berada di permukaan laut tersebut

3. Nau koti bagian laut yang memiliki kedalam 25 meter sampai 100 meter, bagian dasarlaut ini tidak nampak dari permukaan dan pada kedalaman ini warna air laut kebirubiruan

4. Beta nau, bagian laut yang memiliki kedalaman 100 sampai ke zona laut lepas, atau laut bebas kearah Samudera Pasifik, (Wiklif Yarisetouw, 2009) 
Kelompok kelompok yang menguasai wilayah laut pada suku bangsa Yokari adalah, sebaia berikut; Kapung Meukisi kelompok klen Wanya Oko, klen kesepo , kampung Bukisi, kelompok Klen, Matiseray, Ondoafo, Yarona, Kampung Endokisi Kelompok klen Demena, kelompok klen Depario, akmpung Demoikisi, Kelompok klen, Taplamilena Yarisetouw, kelompok klen Yumilena, Kampung Seroyena kelompok klen Kesepo.klen-klen yang menguasai wilayah laut juga termasuk dlam kelompok klen Kaniyo, mengapa Karena, mereka sebagai kelompok pertama pemilik tanah yang menguasai tanah dan laut, dengan menguasai berbagai mantar yang berkaitan dengan sumbe mata pencaharian hidup.

Untuk pelarangan wilayah laut ini juga dilakukan oleh kelompok Kaniyo, dan Yowari, dan kelompok yang sama melakuikan pelarangan pada wilayah darat mereka juga yang melakukan tiatiki untuk laut, dan semua upacara tersebut di bahas dan dilakukan diatas batu lingkaran, ondoafi dengan mengundang semua Touna Yarise yang ada di kampung untuk menyepakati dan menetapkan tiatiki tersebut agar, mereka kembali dapat di sampaikan ke masing-masing kelompok klen untuk diataati dan dilaksanakan.

\subsubsection{Ruang Udara}

Terkait dengan ruang udara Suku-bangsa Yokari, berdasarakan hasil wawancara, mereka memiliki pengetahuan untuk menmanfaatkan benda-benda yang ada di udara sebagi sumber pengetahuan untuk mengetahui perkembangan cuaca dan juga benda benda dilagit sebagi tanda kehadiran dewa tertinggi dalam kehidupan mereka; bendabenda tersebut adalah; burung-burung, angin, awan, hujan, dan petir, serta mata hari. Sejak dahulu suku-bangsa yokari sudah memngenal jenis burung. Ada beberapa jenis burung yang dapat di fungsikan sebagi pesuru untuk maksud tertentu, dan ada pula jenis burung yang di manfaatkan untuk menunjukan siapa yang akan menjadi kepala atau pemimpin, misalnya burung cendera wasih, mambruk, kakatua, dan beberapa jenis burung lainnya.

Pengaturan dan pemanfaatan ruang udara, pada suku bangsa yokari adalah memanfaatkan awan untuk membuat hujan berdasarkan pengetahuan dan mantramantar, juga dpat menghentikan hujan, dan dapat membuat angin untuk di manfatkan untuk keperluan upaya mata pencaharian hidup. Terkait dengan ilmu perbintangan atau astronomi Suku-bangsa Yokari mengenal dua bintang, diantaranya adalah bintang pada pagi hari menjelang fajar terbit di timur, bintang tersebut mereka menyebut dalam bahasa adalah "kisi waryei" dan bintang ini sangat berhubungan erat dengan kepercayaan dari kelompok Yowari, berkaitan dengan pemerintahan keondoafian untuk memberikan tanda sumber berkat dan kekuatan dalam kepemimpinan tersebut.karena bintang ini sebagai pesuru dari matahari yang lebih dahulu menyampaikan bahwa akan terbit matahari di hari yang baru ini.

Sedangkan bintang " nina wariyei" adalah bintang petang yang selalu muncul di bagian barat setelah turunnya matahari, bintang ini berkaitan erat dengan kelompok Yowari, karena ketika muncul bintang "nina wariyei" semua pintu-pintu berkat terbuka, agar hewan liar, di darat atau di lau, tetapi pada malam hari hewan liar tersebut akan keluar dan dapat kita jumpai, baik di darat ataupun dilaut, mereka percaya bintang tersebut juga memeberitaukan bahwa mata hari telah turun. 
Mereka percaya bahwa jenis burung ini merupakan wujud dari nenek moyang mereka. Angin juga merupakan sebuah sarana yang dapat di manfaatkan untuk menuntun mereka mengarungi lautan dalam pencaharian hidup dan tujuan sosial lainya. Petir juga merupakan sebuah tanda bagi mereka untuk mengetahui cuaca yang akan terjadi, juga berkaitan erat dengan tanda bahwa akan terjadi kematian terhadap pemimpin mereka, atau orang tertua yang mempunyai jasa bagiklen dan kampung. Matahari sebagai dewa yang memberikan penerangan dan kehidupan. Pada suku-bangsa Yokari sehingga ada klen-klen tertentu yang dapat berkomunasi dengan matahri mislanya klen Soning Yufu, soning deme. Menurut mite mereka berasal dari matahari. klen soningyufu dan Soningdeme dapat berhubungan dengan matahari.

Terkait dengan ilmu perbintangan atau astronomi Suku-bangsa Yokari mengenal dua bintang, diantaranya adalah bintang pada pagi hari menjelang fajar terbit di timur, bintang tersebut mereka menyebut dalam bahasa adalah "kisi waryei" dan bintang ini sangat berhubungan erat dengan kepercayaan dari kelompok Yowari, berkaitan dengan pemerintahan keondoafian untuk memberikan tanda sumber berkat dan kekuatan dalam kepemimpinan tersebut.karena bintang ini sebagai pesuru dari matahari yang lebih dahulu menyampaikan bahwa akan terbit matahari di hari yang baru ini.

Sedangkan bintang "nina wariyei" adalah bintang petang yang selalu muncul di bagian barat setelah turunnya matahari, bintang ini berkaitan erat dengan kelompok Yowari, karena ketika muncul bintang "nina wariyei” semua pintu-pintu berkat terbuka, agar hewan liar, di darat atau di lau, tetapi pada malam hari hewan liar tersebut akan keluar dan dapat kita jumpai, baik di darat ataupun dilaut, mereka percaya bintang tersebut juga memeberitaukan bahwa mata hari telah turun.

Konsep tata ruang udara dalam suku bangsa yokari dipahami oleh beberapa kelompok dan klen-klen yang berkaitan pengetahuan tentang awan hitam, (aneko) petir, (warpa) hujan (bi) angin (aru) ada angin timur (ana) dan angin barat(yepa) serta angin darat (wau) dan juga matahari (soning) bulan (oko) dan bintang (meya) konsepsi ini berkaitan dengan sistim mata pencaharian hidup, dan juga aktivitas kepemimpinan dan penguasaan serta religi, mata pencaharian hidup, sistem pengetahuan.

\subsection{Bentuk dan Pendayagunaan Ruang Sosial Budaya Suku Bangsa Yokari Dalam Program Pemberdayaan Masyarakat}

Robinson (1994) menjelaskan bahwa pemberdayaan adalah suatu proses pribadi dan sosial; suatu pembebasan kemampuan pribadi, kompetensi, kreatifitas dan kebebasan bertindak. Ife (1995) mengemukakan bahwa pemberdayaan mengacu pada kata "empowerment," yang berarti memberi daya, memberi "power" (kuasa), kekuatan, kepada pihak yang kurang berdaya. Pemberdayaan Komunitas: suatu proses pembangunan di mana masyarakat berinisiatif untuk memulai proses kegiatan sosial guna memperbaiki situasi dan kondisi diri sendiri. (Hatu2010), Berkaitan dengan program pemberdayaan yang dilakukan juga konsep kampung adat yang sudah berjalan di kabupaten jayapura, tentunya tidak terlepas dari konsep konsep masyarakat yang membantu memberikan kontribusi secara kontekstual dalam program pemeberdayaan dan juga program kampung adat yang di canangkan. Untuk mencapai target dan sasaran pembangunan maka konsep konsep kearifan lokal perlu 
untuk di adopsi masuk kedalam sitim pemerintahan, agar dapat mempermuda jangkauan pembangunan.

Berkaitan dengan konsep pemberdayaan dan konsep kampung adat diatas,Suku bangsa yokari telah memiliki pengetahuan untuk mengatur rung lingkungan kebudayaan mereka berdasarkan kelompok-kelompok masyarakat, yang seperti pada uraian di atas telah dikemukahkan, bahwa suku bangsa yoakri terbagi kedalam empat kelompok besar, dengan sistim kepemimpinan politik adalah ondoafi, yang masingmasing mempunyai tugas dan fungsi untuk mengendalikan ruang sosial budaya mereka. Ada suku bangsa yokari juga terbagi kedalam empat kelompok besar dan menempati lima kampung diwilayah suku bangsa yokari, lima kelompok ini disebut Kaniyo, Yowari, Yepei, dan Yepei Yowari. yang menguasai hak ulayat atas tanah, ada kelompok yang menguasai ruang laut, dan ada kelomopk yang menguasai, ruang udara, semua ruang-ruang kebuadyaan ini dikuasai berdasarka sejarah asal usul yang jelas, dan memiliki norma-dan aturan sebagai control atas aktivitas kehidupan mereka

Pendekatan pemberdayaan kearifan lokal diharapkan dapat menimbulkan terjadinya perubahan dasar perilaku sosial yang berkaitan dengan perilaku konservasi air dan tanah. Perubahan tersebut hanya dapat terlaksana apabila secara penuh didasarkan pada kesadaran, keikhlasan, dan kesungguhan dari seluruh pihak (stakeholders) dalam proses mobilisasi sosial. Perubahan perilaku dan struktur sosial dalam hal ini berkaitan dengan nilai, norma, dan pranata yang menjadi nafas kehidupan masyarakat ke arah yang lebih baik dan permanen (Stanis, 2005). Kearifan lokal, budaya, dan norma agama yang dianut dan ditaati oleh masyarakat harus dijaga dan dilestarikan. Beberapa hal yang dapat dilakukan untuk mempertahankannya menurut Siswadi, dkk. (2011) antara lain: (1) penguatan semangat komunitas adat dan agama melalui berbagai tenaga penggerak seperti pemerintah, ahli lingkungan, dan tokoh agama; (2) peningkatan kesadaran, pemahaman, kepedulian, dan partisipasi masyarakat menuju masyarakat yang arif lingkungan; serta (3) penyediaan payung hukum.

Pemerintah Kabupaten Jayapura telah memiliki visi dan misi penguatan kelembagaan masyarakat adat. Visinya adalah mewujudkan Jayapura Baru yang Berjati Diri, Berpemerintahan yang Baik, Cerdas, Sejahtera Harmonis dan Damai, Yang berdaya Saing. Sedangkan misinya adalah memperkuat hak-hak adat dan memberdayakan masyarakat berkelanjutan. Sesungguhnya visi misi Pemerintah Kabupaten (Pemkab) Jayapura ini telah diperkuat oleh sejumlah peraturan perundang-undangan. Sejumlah UU dan peraturan yang memperkuat visi misi tersebut ialah UU No. 21 Tahun 2001, tentang Otonomi Khusus Bagi Provinsi Papua; UU No. 6 tahun 2014 tentang Desa; PP No. 43 Tahun 2014 tentang peraturan pelaksana UU No 6/2014; Permendagri No. 52/ 2014 tentang pengakuan dan pengelolaan masyarakat hukum adat; Perda Kab. Jayapura No. 8/ 2012 tentang Kampung; Keputusan Bupati Jayapura, No. 319/ 2014 tentang pengakuan dan perlindungan Masyarakat hukum Adat di Kabupaten Jayapura; dan No. 320 tahun 2014 tentang Pembentukan 36 (Tiga Pulu Enam) Kampung adat di Kabupaten Jayapura.

Adapun UU No. 21/ 2001 tentang Otsus Bagi Provinsi Papua menghendaki terwujudnya nilai-nilai dan hak-hak adat yang terkandung dalam UU OTSUS seperti keberpihakan, pengakuan, penghormatan, pemberdayaan dan perlindungan atas hakhak dasar serta hak-hak hidup masyarakat adat yang sejak lama telah terikat dengan 
ikatan kesatuan struktur adat istiadat dan sosial budayanya. UU No. 6/ 2014, PP No. 43/ 2014 dan Permendagri No. 52/ 2014 menghendaki desa menjadi desa adat sesuai dengan nilai-nilai kearifan lokal serta pengelolaan dan pelestarian masyarakat adat. Perda Kabuaten Jayapura No. 8/ 2012 menghendaki semua kampung yang ada di Kabupaten Jayapura berbasis nilai-nilai adat yang dimiliki setiap Kampung. Keputusan Bupati Jayapura, No 319/ 2014 dan No 320/ 2014 mengangkat jati diri atau identitas masyarakat adat komunitas etnik Tabi melalui penguatan dan pengelolaan masyarakat adat.

Untuk mewujudkan visi misi dan sejumlah peraturan perundang-undangan tersebut, sejak tahun 2012 hingga 2015, telah dilakukan semua upaya dan cara, menyampaikan konsep dan sosialisasi kepada masyarakat adat mengenai penguatan pemerintahan kampung adat di Sembilan (9) wilayah adat yaitu Bhuyakha, Moi dan Elseng, Tepra, Ormu, Yokari, Youwwarry, Demutru dan Oktim,. Namun masalah yang dihadapi adalah pertama, pemerintah Kabupaten Jayapura belum memiliki model atau alternatif bagaimana membangun model kampung adat. Kedua, Pemerintah Kaupaten Jayapura belum memiliki data mengenai nilai-nilai adat yang relevan dengan membangun model kampung adat yang direncanakan pemerintah Kabupaten Jayapura. Implikasinya adalah sampai saat ini pemerintah Kabupaten Jayapura belum melaksanakan pemerintahan kampung adat, karena: 1) pemerintah belum konsisten mendorong kampung adat; 2) pemerintah melalui SKPD BPMK belum mampu nenerjemahkan visi dan misi bupati dan wakil bupati kabupaten Jayapura; 3) BPMK juga belum memiliki petunjuk, panduan, model serta informasi nilai-nilai adat terkait dengan kampung asli yang mau dijadikan kampung adat; 4) semangat masyarakat ada tetapi belum sepenuhnya didampingi dan dikawal; 5) adanya dualisme kepemimpinan dan tumpang tindi kewenangan di tingkat kampung. 6) batas-batas wilayah adat termasuk kampung masih menjadi masalah dan masih belum jelas. Enam poin inilah yang menyebabkan proses kampung adat ini belum berjalan efektif sesuai dengan rencana, niat dan harapan.

Nilai-nilai adat yang relevan sebagai sebuah model kampung adat yang perlu dibangun berkaca pada tiga kampung adalah: 1) Kampung Nendali yang muatannya: Sejarah Kampung Nendali, Meramu Ikan, Bahasa Yang Digunakan, Khombo:Tempat Upacara Inisiasi, Upacara adat, Obee (balai musyawarah), Tempat Keramat, Aming, Struktur Kepemimpinan; 2) Kampung Waibron: Wasibyaup: Tempat Upacara Inisiasi, Sejarah Kampung Waibron, Bahasa Yang Digunakan, Penduduk Asli Setempat, Demodia, Mitos Waibron; 3) Beberapa kampung Suku Bangsa Elseng: Kondisi Geografis, Sejarah Suku Bangsa Elseng, Mitos Penciptaan Orang Elseng, Hak Ulayat Adat, Peran dan Fungsi Marga Dalam Struktur, Makan Papu, Struktur Kepemimpinan. Nilai-nilai ini perlu diangkat dan dipelajari sebagai filososfi membangun model kampung adat.

Nama distrik dan kampung yang disesuaikan dengan nilai-nilai adat. Nama Distrik Misalnya, Distrik Sentani Timur menjadi Ralibhu, Distrik Sentani menjadi Nolobhu/Bhuyakha, Distrik Waibhu: Sentani Barat, Distrik Sentani Barat menjadi Moi. Nama Kampung Desa atau Desa adat (kampung atau Kampung adat) dapat disesuaikan dengan Pasal 96-111 UU No 62014 dan PP 43 2014. Dalam UU ini dikatakan desa adat dapat dilakukan dengan cara "gabungan atau desa diubah desa adat atau desa adat diubah desa". 
Rumah Adat dan Tempat Musyawarah sebagai wujud dari pelestarian nilai-nilai budaya. Dibangunnya kembali rumah adat masing-masing Komunitas adat misalnya Khombo: rumah adat orang Bhuyakha, Wasibyaup: rumah adat orang Waibron, Saliyap: rumah adat orang Elseng. Nama para-para adat (tempat musyawarah) diganti dengan Obee untuk Orang Bhuyakha, Dmo Dya: untuk orang Moi, dan Koy Dea: untuk orang Elseng. Nilai-nilai inilah menjadi kekhasan membangun model pemerintahan adat. Struktur kepemimpinan dan kewenangan menjadi penting karena pemerintah Kabupaten Jayapura dalam pertemuan formal maupun nonformal selalu menyampaikan konsep mengenai pemerintahan kampung adat.

\section{Kesimpulan}

Struktur sosial yang berbentuk kelompok kelompok klen-klen dalam suku bangsa Yokari yang terbagi menjadi empat kelompok besar yaitu (1) Kaniyo, sebagai kelompok yang berkuasa atas tanah, (2) Kelompok Yowari adalah kelompok yang berhubungan dengan religi, (3) Kelompok Yepei adalah kelompok yang berhubungan dengan pemerintahan, serta pengamanan terhadap suku bangsa dari serangan musuh, dan (4). kelompok Yepei Yowari adalah kelompok ini berperan baik sebagai kelompok pemerintahan dan juga religi. Masing-masing kelompok tersebut, menguasai ruang darat, laut dan udara, dibawah pengendalian ondoafi berdasarkan norma-norma yang berlaku.

Tata ruang suku bangsa Yokari adalah ruang darat yang dikuasai oleh kelompok Kaniyo, seperti tanah dan hutan, serta sumber mata pencaharian hidup yang terdapat di darat dan permukiman. Ruang laut dikuasai oleh kelompok Kaniyo dan Yowari, berkaitan dengan penangkapan ikan dan pengetahuan tentang terumbu karang. Sedangkan Ruang udara dikuasai oleh klen Soning Yufu dalam suku bangsa Yokari untuk maksud-maksud tertentu.

\section{Daftar Pustaka}

Eko Budihardjo. (1999). Kota Berkelanjutan. Bandung: Penerbit Alumni.

Hall, E. T. (1959). The Silent Language. New York: Doubleday.

Koentjaraningrat.(2002). Pengantar Ilmu Antropologi. Jakarta: Rhineka Cipta.

M.Cholil Mansyur. (2005). Sosiologi Masyarakat Kota dan Desa. Surabaya: Usaha Nasional.

Paker.G and Joe Doak. (2012). Key Concept in Planning. British: Replica Press Pvt.Ltd

Radcliffe Brown, A.R. (1952) Structure and Function in Primitive Society. London: Routledge and Kegan Paul.

Radcliffe-Brown, A.R. (1952) Structure and Function in Primitive Society. London: Routledge and Kegan Paul.

Rapoport.A. (1982). The Meaning of The Built Enviroment. California: SAGE Publications.

Soekanto, Soejono. (1983). Struktur Masyarakat. Jakarta: Rajawali. 
Stanis, S. (2005). Tesis: Pengelolaan Sumberdaya Pesisir dan Laut Melalui Pemberdayaan Kearifan Lokal di Kabupaten Lembata Provinsi Nusa Tenggara Timur. Semarang: Program Pascasarjana Universitas Diponegoro

Trancik.R. (1986). Finding Lost Space. America: Library of Congres Catalogue in Publication Data

Tuan.Y. (2010). Space and Place: The Perspective of Experience. London: University of Minnosota Perss.

Yarisetouw, Wiklif. (2003). Thesis: Pengetahuan Lokal tentang Pemanfaatan dan Pelestarian Lingkungan Hidup Masyarakat Pesisir Teluk Tana Merah Kabupaten Jayapura, Depok: UI. 